University of Wollongong

Research Online

Faculty of Engineering and Information

Faculty of Engineering and Information

Sciences - Papers: Part A

Sciences

$1-1-2015$

Piezoelectric polymers as biomaterials for tissue engineering applications

Clarisse Ribeiro

University of Minho

Vitor Sencadas

University of Wollongong, victors@uow.edu.au

Daniela M. Correia

University of Minho

Senentxu Lanceros-Méndez

University of Minho

Follow this and additional works at: https://ro.uow.edu.au/eispapers

Part of the Engineering Commons, and the Science and Technology Studies Commons

Research Online is the open access institutional repository for the University of Wollongong. For further information contact the UOW Library: research-pubs@uow.edu.au 


\title{
Piezoelectric polymers as biomaterials for tissue engineering applications
}

\begin{abstract}
Tissue engineering often rely on scaffolds for supporting cell differentiation and growth. Novel paradigms for tissue engineering include the need of active or smart scaffolds in order to properly regenerate specific tissues. In particular, as electrical and electromechanical clues are among the most relevant ones in determining tissue functionality in tissues such as muscle and bone, among others, electroactive materials and, in particular, piezoelectric ones, show strong potential for novel tissue engineering strategies, in particular taking also into account the existence of these phenomena within some specific tissues, indicating their requirement also during tissue regeneration. This referee reports on piezoelectric materials used for tissue engineering applications. The most used materials for tissue engineering strategies are reported together with the main achievements, challenges and future needs for research and actual therapies. This review provides thus a compilation of the most relevant results and strategies and a start point for novel research pathways in the most relevant and challenging open questions.
\end{abstract}

\section{Keywords}

engineering, tissue, biomaterials, applications, polymers, piezoelectric

\section{Disciplines}

Engineering | Science and Technology Studies

\section{Publication Details}

Ribeiro, C., Sencadas, V., Correia, D. M. \& Lanceros-Méndez, S. (2015). Piezoelectric polymers as biomaterials for tissue engineering applications. Colloids and Surfaces B: Biointerfaces, 136 46-55. 
Piezoelectric Polymers as Biomaterials for Tissue Engineering

\title{
Applications
}

C. Ribeiro ${ }^{1, *}$, V. Sencadas ${ }^{1}$, D. M. Correia ${ }^{1,2}$, and S. Lanceros-Méndez ${ }^{1, *}$

${ }^{1}$ Centro/Departamento de Física da Universidade do Minho, Campus de Gualtar, 4710057 Braga, Portugal.

${ }^{2}$ Centro/Departamento de Química, Universidade do Minho, Campus de Gualtar, 4710057 Braga, Portugal

Corresponding authors: cribeiro@fisica.uminho.pt; lanceros@fisica.uminho.pt

\begin{abstract}
Tissue engineering often rely on scaffolds for supporting cell differentiation and growth. Novel paradigms for tissue engineering include the need of active or smart scaffolds in order to properly regenerate specific tissues. In particular, as electrical and electromechanical clues are among the most relevant ones in determining tissue functionality in tissues such as muscle and bone, among others, electroactive materials and, in particular, piezoelectric ones, show strong potential for novel tissue engineering strategies, in particular taking also into account the existence of these phenomena within some specific tissues, indicating their requirement also during tissue regeneration.

This refere reports on piezoelectric materials used for tissue engineering applications. The most used materials for tissue engineering strategies are reported together with the main achievements, challenges and future needs for research and actual therapies. This referee provides thus a compilation of the most relevant results and strategies and a start point for novel research pathways in the most relevant and challenging open questions.
\end{abstract}

Keywords: tissue engineering; piezoelectric; scaffold; smart materials; polymers 


\section{Introduction}

Metals, alloys and ceramic materials are being replaced by polymers in different application areas including aerospace and automotive industries, electronics, sensors, actuators and tissue and biomedical engineering. Different processing techniques have been developed for the production of polymers with tailored properties, including electrical, mechanical, thermal, chemical and surface properties, among others, addressing specific applications demands [1-2].

Polymers present attractive properties when compared to inorganic materials. They are light weight, inexpensive, mechanically and electrically tough, they show excellent compatibility with other organic and inorganic materials for the development of multifunctional hybrid systems, and some of them are biodegradable and/or biocompatible [3-5].

The increasing advances in materials science and engineering is allowing the improvement and optimization of the so-called smart materials and, in particular, smart polymer materials, for a larger number of application areas [6-10].

Smart materials are materials with reproducible, significant and stable variations of at least one property when subjected to external stimuli. Smart materials are typically classified according to the output response and include piezoelectric materials, materials that develop a voltage when a mechanical stress is applied or vice-versa; shape memory materials, in which a large deformation can be induced and recovered by temperature or stress variations; temperature responsive polymers, magnetostrictive materials, $\mathrm{pH}$ sensitive materials, self-healing materials, thermoelectric materials and conductive polymers, among others [11-13]. These materials are also generally knows as active materials.

Particularly interesting for sensor and actuator applications, are materials that undergo deformation under a specific stimuli or than provide a specific stimuli under mechanical force and/or deformation. Depending on the transduction mechanism, they can be broadly classified as non-electrically deformable polymers (actuated by non-electric stimulus such as $\mathrm{pH}$, light and temperature, for example) and electroactive polymers (EAP) when the transduction mechanism involves electro-mechanical coupling. The later are further classified as dielectric EAP, which electromechanical response is dominated by electrostatic forces and ionic EAP which actuation mechanism involves 
the diffusion of ions [14-15]. The main types of electroactive polymers are shown in table 1. Electrically conductive polymers are another class of electrically active materials that is attracting increased attention as they show simultaneously high conductivity and the physico-chemical properties of polymers [16-18].

Table 1: Leading types of EAP materials (from [15]).

\begin{tabular}{|c|c|}
\hline Electronic EAP & Ionic EAP \\
\hline Dielectric EAP & Ionic polymer gels (IPG) \\
\hline Electrostrictive graft elastomers & $\begin{array}{l}\text { Ionic polymer metal composites } \\
\text { (IPMC) }\end{array}$ \\
\hline Electrostrictive paper & \\
\hline Electro-viscoelestastic elastomer & Conducting polymers \\
\hline Ferroelectric polymers & $\begin{array}{l}\text { Carbon nanotubes (CNT) and } \\
\text { nanofibers (CNF) }\end{array}$ \\
\hline Liquid crystal elastomers (LCE) & \\
\hline
\end{tabular}

In the last decades, a variety of natural and synthetic materials with various molecular designs emerged as potential biomaterials for tissue and biomedical engineering [19]. Natural materials are attractive for biomedical and related applications as they are obtained from natural sources, exhibiting similar properties to the tissue they are replacing, many of them containing specific cues for cell adhesion and proliferation and allowing cell infiltration [20]. On the other hand, polymers from natural origin are often difficult to process and show poor mechanical and electrical properties [21]. In this way, a variety of synthetic polymers such as poly(lactic acid) (PLA) [22-23], poly(glycolic acid) (PGA) [24-25], poly(lactic-co-glycolic acid) (PLGA) [26-27], poly(ethylene glycol) (PEG) [28-29] and polycaprolactone (PCL) [30] have been widely used to produce materials/scaffolds for tissue engineering [31].

Although an extensive list of polymer has been studied regarding tissue engineering applications, most of the developed scaffolds have been used in a passive way, just as support for the cells and tissues [32]. Nevertheless, it was verified that for some specific cells and tissues, the active behavior of the material used for the scaffold development can be taken to advantage, providing even the necessary stimuli for proper tissue 
regeneration. This fact gave rise to the strong increase of the development of smart materials for tissue engineering applications [33].

Being electrical signals one of the main physical stimuli present in the human body and, in particular, the electromechanical signals, this review is devoted to summarize the research efforts, main conclusions, main challenges and needs as well as the strong potential of developing electroactive scaffolds based on piezoelectric polymers for specific tissue engineering applications.

In a piezoelectric material, an electrical response due to mechanical excitation or vice versa can be observed. In these kind of materials a certain directionality in its structure was required. The synthetic polymers that are in noncrystalline or semicrystalline form and are originally isotropic can be subjected to a special treatment (such as corona) to meet this requirement [34]. By definition, the piezoelectric effect can be described by four piezoelectric coefficients $d_{i j}, e_{j}, g_{i j}$ and $h_{i j}$, wherein the most common used, the direct effect, is the $d_{i j}$ coefficient (Equation 1).

$$
d_{i j}=\left(\frac{\partial D_{i}}{\partial X_{j}}\right)^{E}=\left(\frac{\partial x_{i}}{\partial E_{j}}\right)^{X}
$$

where $D$ is the electric induction; $E$ is the electric field strength; $X$ is the mechanical stress; and $x$ is the strain [35]. In this sense, it is possible observe that the piezoelectricity is the relation between the electrical variables ( $D$ and $E$ ) and the mechanical parameters $(\mathrm{X}$ and $x$ ).

The inverse piezoelectric effect is the $\mathrm{e}_{\mathrm{j}}$ coefficient (Equation 2).

$$
e_{i j}=\left(\frac{\partial D_{i}}{\partial x_{j}}\right)^{E}=-\left(\frac{\partial X_{i}}{\partial E_{j}}\right)^{x}
$$

The direct piezoelectric effect $\left(d_{i j}\right)$ concerns the conversion of the mechanical energy to the electrical energy while the inverse piezoelectric effect $\left(e_{i j}\right)$ is the conversion of the electrical energy to the mechanical energy.

2. Electrical clues in human body

Many of the major functions in cells and organs of the human body are controlled by electrical signals. As early as in the $18^{\text {th }}$ century it is described the use of electrostatic charge for skin lesion treatment [36] and in 1983, electrical potentials ranging betwœen 10 and $60 \mathrm{mV}$ depending on the human body location were measured [37]. 
Electric fields and potentials induce distinct effects on cells and it has been proven that small applied electric fields can guide a variety of different cell types to move and migrate directionally such as corneal, epidermal and epithelial cells [38-41]; can modulate the phenotypes of vascular endothelial cells [42]; can regenerated nerve fibers [43] and are widely used in orthopedic practices, showing the improvement of ligament healing in vivo [44].

3.1. Piezoelectricity in human body

Extensive and classic studies of the piezoelectric properties of bone and other biological materials have been also reported. The piezoelectricity can be referred as a extended property of living tissue, playing a significant role in several physiological phenomena [45]. Piezoelectricity can be thus found in different parts of the human body (figure 1) such as bone, tendon, ligaments, cartilage, skin, dentin, collagen, deoxyribonucleic acids (DNA) and conceivably, in cell membranes [45-50].

\section{Electric}

Corneal cells

Epidermal cells

Nervous system

Retinal cells

Vascular endothelial cells

\section{Piezoelectric}

\author{
Bone \\ Cartilage \\ DNA \\ Ligaments \\ Skin \\ Tendons
}

Figure 1 - Representative human body location in which electrical and piezoelectric signals are relevant. 
Bone

Bone is a dynamic tissue in constant adaptation and remodeling through complex feedback mechanisms, involving electromechanical processes, due to its piezoelectric characteristics. Due to its piezoelectric nature, bone is the paradigm for piezoelectric electromechanical effect in human tissue [51].

The first study reporting the piezoelectric properties of the bone was in 1955 [52]. Few years later, electric currents in bone and the generation of electric potentials when the bone is mechanically stressed were verified [53-54]. This phenomenon, recognized as piezoelectricity, is independent of the cell viability. The mechanical stress produces electrical signals and these signals represent the stimulus that promotes bone growth and remodeling according to the Wolff's law [55]. The biomechanical properties of bone, in particular its piezoelectric activity, have been addressed microscopically [56] and macroscopically, with models using finite element analysis [57]. Further, it has been also hypothesized a mechanism by which the piezoelectric signals can regulate the bone growth [58]. At the cellular level, the bone cell type that plays an important role in the bone structure development and appears to be involved in bone mechanotransduction, the osteocytes, was identified [59]. Consequently, for bone regeneration, these cells communicate with other bone cells, such as osteoblasts and osteoclasts. The influence of electrical stimulation on bone healing has been studied in vitro [60-66] and in vivo [67-72] and it has been demonstrated that the application of these stimulus can enhance and stimulate osteogenic activities. In this way, the osteoblasts are affected by electromechanical signals to apposite bone tissue [73-74], the piezoelectric nature of bone, leading to natural conversion of the mechanical stimuli into electrical ones.

Collagen and others piezoelectric tissues

Due to their collagenous structure, tendons and ligaments also exhibit piezoelectricity, giving rise, therefore, to an electrical potential variation when a mechanical stress is applied [75-76]. The piezoelectricity of dry tendons was measured [77], as well as the electrical potentials generated in hydrated tendon [78-79], the piezoelectric coefficient decreasing with increasing hydration [80].

Piezoelectric effect has been also observed in different soft tissues, such as skin, callus, cartilage and tendons, as well as in hard ones, such as bone, and appears to be associated with the presence of oriented fibrous proteins [45, 81]. All connective tissue 
contains one or more types of fibrous molecules such as collagen, keratin, fibrin, elastin, reticulum or cellulose structure, showing also piezoelectric properties [45].

It seems evident from the literature that the piezoelectric effect can be attributed to the main organic constituent of tissue, which is collagen in the case of the bone and tendons [82-83]. Thus, it has been shown that the crystalline unit of collagen is polar hexagonal $\left(\mathrm{C}_{6}\right)$ [56], showing piezoelectric properties. Further, as previously indicated, it has been shown that dry bone is piezoelectric, i.e., a mechanical stress induces a polarization (direct effect) and an application of an electric field produces a change in the material geometry or strain (converse effect). It was reported that for dry fibers, the polarization results from the displacement of the hydrogen bonds formed in the polypeptide chains of the collagen crystals. Other studies confirmed such findings. Thus, in [84] the piezoelectric and pyroelectric behavior of collagen were measured independently from the bone, confirming that the electroactive properties arise from the structure of collagen molecules. It was suggested that the crystalline structure of collagen changed under wet conditions and that the bound water promotes a change its crystal symmetry to the point where no piezoelectric properties were observed [78, 85]. A certain minimum amount of water concentration, which increases the crystal symmetry, is nevertheless required to maintain the overall structural integrity. Further, it was also suggested that, due to the variability of the electroactive behavior of collagen in wet and dry states, wet bone shows different piezoelectric symmetry relation [78, 85]. More recently, studies of the piezoelectric response of human bone using a piezoresponse force microscope, in order to measure this effect at nanometer scale resolution directly in the collagen matrix, resulted in the quantification of the piezoelectric response in 7 8 pC. $\mathrm{N}^{-1}$ [86].

With respect to other biological tissues, the electrical polarization variations were also verified in hair when subjected to stress [87] as well as in DNA [75]. Finally, investigations in the calcifications commonly found in human pineal gland tissues resulted in the determination that the pineal gland contains non centrosymmetric material which, according to crystallographic symmetry considerations, is also piezoelectric [88].

3. Electrically active materials for tissue engineering 
Advances in the understanding of electrical properties of tissues and cells are increasingly attracting attention to this area of research. Living cells show many properties of electrical systems, i.e., they generate electromotive force, regulate the potential difference whenever needed, use varying resistances in series or in parallel, switch on and off, control and rectify current flow and store charge [89-90]. An electric voltage exists across the plasma membrane, while the inside of the cell remains more negative than the outside. By convention, the potential outside the cell is called zero; therefore, the typical value of the membrane potential is in the range of -60 to $-100 \mathrm{mV}$ [91].

Thus, conductive polymers have been applied in tissue engineering applications. One of the most studied conductive polymers for tissue and biomedical engineering is polypyrrole (PPy) that has been proven to be a promising substrate for cell growth and proliferation, in particular for axon growth in vitro and in vivo experiments [90, 92]. Studies reveal that the application of an external electrical stimulus to the material, and consequently to the cell, enhances axons outgrowth to levels beyond the ones obtained for cultures on non-conducting polymers [92-93]. One of the major drawbacks of the used conductive polymers for in vivo applications is their inherent inability to biodegradation, which may induce chronic inflammation and require surgical removal [94]. In order to solve this issue, attempts to blend them with suitable biodegradable polymers have been carried out. Thus, nerve guidance channels (NGCs) were fabricated from an electrically conductive, biodegradable polymer of PPy and poly(D,L-lactide-coepsilon-caprolactone) (PDLLA/CL) [92]. Further, the influence of the applied current intensity in the neurite outgrowth was evaluated and it was found that a current intensity of $1.7-8.4 \mu \mathrm{A} / \mathrm{cm}$ leads to the largest enhancement of neurite outgrowth on conductive PDLLA/CL and PPy surfaces.

Polyaniline (PANI) is the oxidative product of aniline under acidic conditions and is commonly known as aniline black [95] and the ability of PANI and PANI variants to support cell growth has been evidenced [96], independently of the oxidation state [97]. In this way, adhesion and proliferation of cardiac myoblasts (H9c2) on conductive PANI substrates have been reported [98]. Both non-conductive emeraldine base and conductive salts forms of PANI were found to be biocompatible and to support cell attachment and proliferation, which attracted much attention of this material for tissue and biomedical applications. Further, there are other electrically conductive polymers 
that are being studied for tissue and biomedical engineering such as poly(3, 4ethylenedioxythiophene) (PEDOT) for cochlear implants, vision prosthesis, neural regeneration devices and neural recording electrodes [99].

Carbon nanotubes (CNTs) are other group of conducting fillers incorporated into nonconductive polymers to provide structural reinforcement and electrical conductivity into the scaffolds and to direct cell growth [100]. Some studies indicated that CNTs are cytotoxic, while others revealed that carbon nanotubes are excellent substrates for cellular growth [100]. As a result of these studies, it is claimed that when used in suspension, CNTs seems to be toxic to cells, while they appear to be non-toxic if immobilized into a specific polymer matrix or culture dish [101].

Table 2 summarizes some relevant experimental conditions and cells used for electrical stimulation based on electrically conductive polymers. These materials have been particularly explored for neural development and it was verified that the application of electric fields influence the rate and orientation [43] and also the extension and direction [102] of the neurite outgrowth of cultured neurons in vitro.

Table 2: Relevant works on electrical stimulation conditions applied in tissue engineering strategies based on conductive polymers (adapted from [90]).

\begin{tabular}{|c|c|c|c|}
\hline Conductive Scaffolds & $\begin{array}{c}\text { dc/ac current; } \\
\text { potential }\end{array}$ & Duration & Cells \\
\hline PANI/PCL/gelatin & dc: $100 \mathrm{mV}$ & $1 \mathrm{~h}$ & $\begin{array}{l}\text { Mouse neuronal } \\
\text { cerebellum stem } \\
\text { cells (C17.2) }\end{array}$ \\
\hline $\begin{array}{l}\text { PANI/poly(L-lactide-co- } \varepsilon- \\
\text { caprolactone) } \\
\text { (PANI/PLACL) }\end{array}$ & dc: 0 - $200 \mathrm{~mA}$ & $48 \mathrm{~h}$ & NIH-3T3 fibroblasts \\
\hline PPy & dc: $100 \mathrm{mV}$ & $2 \mathrm{~h}$ & $\begin{array}{c}\text { Rat neuronal } \\
\text { phaeochromocytoma } \\
\text { (PC12) }\end{array}$ \\
\hline PLGA coated with PPy & $10 \mathrm{mV} \mathrm{cm}^{-1}$ & $2 \mathrm{~h}$ & PC12 \\
\hline $\begin{array}{c}\text { PPy/poly(L-lactic acid) } \\
\text { (PPy/PLLA) }\end{array}$ & dc: $100 \mathrm{mV} \mathrm{mm}{ }^{-1}$ & $2,24 \mathrm{~h}$ & $\begin{array}{l}\text { Human skin } \\
\text { fibroblasts }\end{array}$ \\
\hline $\begin{array}{c}\text { PDLLA/CL coated with } \\
\text { PPy }\end{array}$ & $\begin{array}{l}\text { dc: } 0,2,8 \text { e } 20 \mu \\
\text { A mm } \mathrm{mm}^{-1} \mathrm{mV}^{-1}\end{array}$ & - & PC12 \\
\hline PPy & ac: $50 \mu \mathrm{A}$ at 0,05 , & - & Vascular smooth \\
\hline
\end{tabular}




\begin{tabular}{|c|c|c|c|}
\hline PPy/PLLA & 5 and $500 \mathrm{~Hz}$ & $\begin{array}{c}\text { muscle cells } \\
\text { (VSMC) }\end{array}$ \\
\hline Indium-tin oxide (ITO) & $\begin{array}{c}\text { ac: } 100 \mathrm{mV}(100 \\
\mathrm{Hz})\end{array}$ & $\begin{array}{c}30 \mathrm{~min} / \text { day } \\
(3 \text { days })\end{array}$ & $\begin{array}{c}\text { Human cutaneous } \\
\text { fibroblasts }\end{array}$ \\
\hline PLLA/CNT & $\begin{array}{c}\mathrm{ac}: 10 \mathrm{~mA}(10 \\
\mathrm{Hz})\end{array}$ & 6 h/day & Osteoblasts \\
\hline PCL/PPy & dc: $10 \mathrm{~V}$ & $4 \mathrm{~h} /$ day & $\begin{array}{c}\text { Dorsal root ganglia } \\
\text { (DRG) }\end{array}$ \\
\hline PPy & $\begin{array}{c}\text { Biphasic } 100 \mu \mathrm{s} \\
\text { pulses of } 1 \\
\mathrm{~mA} . \mathrm{cm}^{-2} \text { at } 250 \\
\mathrm{~Hz}\end{array}$ & $8 \mathrm{~h} /$ day & $\begin{array}{c}\text { Cochlear neural } \\
\text { explants }\end{array}$ \\
\hline $\begin{array}{c}\text { copolymer of } \\
\text { hydroxyl-capped PLA and } \\
\text { carboxyl-capped aniline } \\
\text { pentamer (AP) (PLAAP) }\end{array}$ & $\begin{array}{c}\text { Electric potential } \\
\text { of } 0.1 \mathrm{~V}(1 \mathrm{~Hz})\end{array}$ & $1 \mathrm{~h} /$ day & PC12 \\
\hline PPy/Chitosan & dc: $100 \mathrm{mV}$ & $4 \mathrm{~h}$ & Schwann Cells \\
\hline
\end{tabular}

Common to the aforementioned materials is the need of an external power supply in order to induce electrical signals and thus to promote electrical stimulus to the cells. This is a strong drawback for in-vivo applications and thus, it is important to develop a generation of biomaterials including combinations of biological, chemical, mechanical and electrical stimulatory cues, being the last ones without external power supply and therefore wires.

In this scope, piezoelectric polymers appear as a possibility for applying electrical signals to the cells by mechanoelectrical transduction. Piezoelectric materials generate transient surface charge variations and therefore electrical potential variations when mechanical solicitation are applied to the material and, therefore, no need for additional energy sources or electrodes [103] are requires.

4. Piezoelectric soft biomaterials and structures

General for all materials used as scaffolds, the design of these bioactive biomaterials is another important parameter to consider and a suitable morphology, in combination to the piezoelectric characteristics, has to be optimized proper cell response. 
Many processing methods have been developed to process biomaterials into scaffolds with different dimensionalities and morphologies [104-105]. Different structures of biomaterials including microspheres, fibers, porous membranes, hydrogels and sponges have been designed and used in tissue engineering [19]. However, effects of internal biomaterials structures remain largely unexplored and the comparison of cell response in the different structures types remains elusive. In particular, just a few scaffold morphologies have been used for piezoelectric tissue engineering including films, membranes and fibers, among others. Some structures of -poly(vinylidene fluoride) (PVDF) are shown in Figure 2.

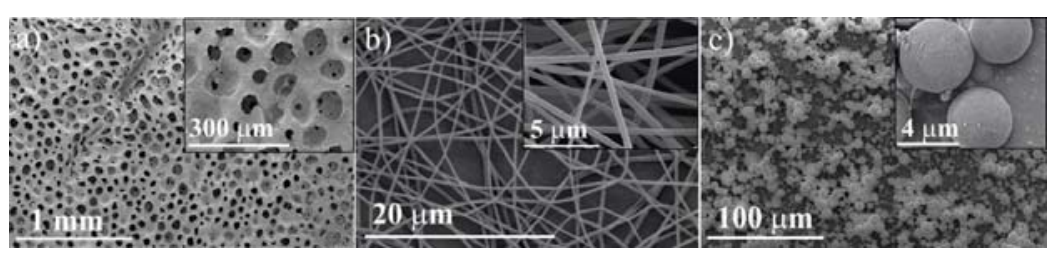

Figure 2 - -PVDF obtained in different morphologies: a) porous membranes, b) electrospun fibers and c) microparticles.

Porous scaffolds have been obtained by solvent casting/salt leaching, phase separation, gas foaming, gel casting, precipitation and emulsion freeze-drying [104-105]. The main drawbacks of these methods are associated with the possibility to obtain scaffolds with an inaccurate and limited interconnectivity pore morphology that is disadvantageous for uniform cell seeding and tissue growth [31, 106]. This major drawbacks can be overcome by fibrous scaffolds produced by electrospinning, a method that offers the ability of control the pore interconnectivity and moreover the internal and external morphology of fibers by controlling processing parameters such as applied voltage, solution viscosity and conductivity, among others [106]. Moreover, electrospinning allows the production of scaffolds with small pore size, density and high surface area [105-106]. The pores of the scaffolds should be large enough to allow cell migration, where they eventually become bound to the ligands within the scaffold. Therefore, for any scaffold, a critical range of pore sizes exists, which may vary depending on the cell type and tissue being engineered [107]. The fiber diameter of the scaffolds produced by electrospinning can range from 5 to $1000 \mathrm{~nm}$ [106]. A similar method to electrospinning 
is electrospray, which allows the preparation of polymeric micro- and nanoparticles that can also be used as support for cell expansion and differentiation [108-109]. Other methods can be used for particle formation however this method might overcome some of the drawbacks associated with conventional microparticle-producing methods, such as solvent casting, single and double emulsion, spray-drying, porous glass membrane emulsification and coacervation [108].

More recently, rapid prototyping (RP) technologies also known as solid free-form fabrication (SFF) allows translating computer data files such as computer-aided design (CAD), computed tomography (CT), magnetic resonance imaging (MRI) and convert the digital information through layered manufacturing SFF machines into a 3D scaffold [105-106, 110]. Three-dimensional printing (3DP), fused deposition modeling (FDM), stereolithography apparatus (SLA) and selective laser sintering (SLS) are widely been applied in the fabrication of materials with unique geometries with controllable pore architecture which could not obtained by conventional methods [106, 108]. Various biomaterials are commonly used in RP technologies such as PEG, PLGA, PCL, collagen, starch, HA and TCP [104, 111-112]. However, to the best of our knowledge few studies report the production of piezoelectric scaffolds by these methods. It is known that stereolithography is the most commonly method used for fabricate piezoelectric scaffolds based on PLLA [112].

These scaffold structures have to be achieved with the few natural and synthetic materials exhibiting piezoelectric properties, the most relevant ones, with the respective piezoelectric properties being reported in table 3 and 4 , respectively.

Table 3 - Biodegradable polymers with natural origin and corresponding main piezoelectric response (adapted from [75]).

\begin{tabular}{|c|c|c|c|}
\hline \multicolumn{2}{|c|}{ Natural Polymers } & $\begin{array}{c}\text { Piezoelectric } \\
\text { coefficient } \\
-\mathrm{d}_{14}(\mathrm{pC} / \mathrm{N})\end{array}$ \\
\hline \multirow{3}{*}{ Polysaccharides } & \multirow{2}{*}{ Cellulose } & wood & 0.10 \\
\cline { 2 - 4 } & Chitin & ramie & 0.20 \\
\cline { 2 - 4 } & & crab shell & 0.20 \\
\hline
\end{tabular}




\begin{tabular}{|c|c|c|c|}
\hline & & Iobster apodeme & 1.50 \\
\hline & Amylose & starch & 2.00 \\
\hline \multirow{7}{*}{ Proteins } & \multirow{3}{*}{ Collagen } & bone & 0.20 \\
\hline & & tendon & 2.00 \\
\hline & & skin & 0.20 \\
\hline & \multirow{2}{*}{ Keratin } & wool & 0.10 \\
\hline & & horn & 1.80 \\
\hline & \multirow{2}{*}{ Fibrin } & $\begin{array}{l}\text { elongated films of fi } \\
\text { brinogen-thrombin clot }\end{array}$ & 0.20 \\
\hline & & $\begin{array}{l}\text { Deoxyribonucleic acids } \\
\text { salmon DNA (at }-100^{\circ} \mathrm{C} \text { ) }\end{array}$ & 0.07 \\
\hline
\end{tabular}

However, to take advantage of the piezoelectric properties, synthetic polymers have been chosen instead the natural ones for their use as tissue engineering scaffolds. These have known compositions and can be designed to minimize immune response. They can be tailored to produce a wide range of scaffold geometries and hybrid structures by combining polymers with other organic or inorganic hybrid structures.

Among all polymers, PVDF [113] and vinylidene fluoride (VDF) [114] copolymers, are the synthetic, semi-crystalline polymers with the highest electroactive properties, including piezoelectric, pyroelectric and ferroelectric properties [114].

Table 4 - Piezoelectric natural and synthetic polymers.

\begin{tabular}{|c|c|c|c|}
\hline Polymer & $\begin{array}{l}\text { Dielectric constant } \\
\quad\left(1 \mathrm{kHz} ; 25^{\circ} \mathrm{C}\right)\end{array}$ & $\begin{array}{c}\text { Piezoelectric } \\
\text { Coefficient }(\mathrm{pC} / \mathrm{N})\end{array}$ & Ref. \\
\hline PLA & $3.0-4.0$ & 9.82 & $\begin{array}{r}115- \\
116]\end{array}$ \\
\hline Polyhydroxybutyrate (PHB) & $2.0-3.5$ & $1.6-2.0$ & $\begin{array}{l}{[117-} \\
118]\end{array}$ \\
\hline PVDF & $6-12$ & $24-34$ & $\begin{array}{r}{[119-} \\
120]\end{array}$ \\
\hline $\begin{array}{lr}\text { Poly(vinylidene } & \text { fluoride } \\
\text { trifluoroethylene) } & \text { (PVDF- }\end{array}$ & 18 & 38 & [120] \\
\hline
\end{tabular}




\begin{tabular}{|l|c|c|c|}
\hline TrFE) & & & \\
\hline Polyamide-11 & 5 & 4 & [121] \\
\hline
\end{tabular}

As previously mentioned, it is possible to find electrical activity and even piezoelectricity in many parts of the human body. For that reason, it seems be advantageous to employ biomaterials based on piezoelectric properties for active tissue engineering of specific tissues.

5. Tissue engineering based on piezoelectric polymer s

Studies of the use of piezoelectric polymers for tissue engineering applications are mostly devoted to bone, neural and muscle regeneration.

Table 5 summarizes the main works using piezoelectric polymers, the intended applications and scaffold morphology, together with the cultivated cells. 
Table 5 - Material type, scaffold design and cells used for different applications.

\begin{tabular}{|c|c|c|c|c|}
\hline Applications & Material type & Scaffold design & Cells type used & Ref. \\
\hline \multirow{9}{*}{$\begin{array}{l}\text { Bone } \\
\text { regener ation } \\
\text { or } \\
\text { Bone tissue } \\
\text { engineering }\end{array}$} & \multirow{3}{*}{ PVDF and copolymer } & Films & $\begin{array}{l}\text { MC3T3-E1 } \\
\text { Goat marrow stromal cells into } \\
\text { osteoblast }\end{array}$ & $\begin{array}{l}122- \\
124] \\
{[125]^{*}}\end{array}$ \\
\hline & & Fibers & $\begin{array}{l}\text { Human mesenchymal stem cells } \\
\text { (MSCs) }\end{array}$ & [126] \\
\hline & & Blends membranes (porous) & NIH3T3 mouse fibroblast & [127] \\
\hline & \multirow[b]{2}{*}{ PLLA } & Films & Implementation on male cats & [128] \\
\hline & & Fibers & $\begin{array}{l}\text { Human fetal osteoblasts (hFOB) } \\
\text { Human mandible-derived } \\
\text { mesenchymal stem cells (hMSCs) }\end{array}$ & $\begin{array}{l}{[129]} \\
{[130]}\end{array}$ \\
\hline & \multirow{3}{*}{ PHB and copolymers } & Films & Bone marrow cells & [131] \\
\hline & & Fibers & $\begin{array}{l}\text { Human osteoblasts (HOB) } \\
\text { Bone marrow cells }\end{array}$ & $\begin{array}{l}{[132]} \\
{[131]}\end{array}$ \\
\hline & & $\begin{array}{l}\text { 3D Blends membranes } \\
\text { (porous) }\end{array}$ & МС3T3-E1 & [133] \\
\hline & Collagen & $\begin{array}{l}\text { Fibers - hydrogel D-periodic } \\
\text { type I collagen fibrils }\end{array}$ & Rat tail tendon & [134] \\
\hline
\end{tabular}

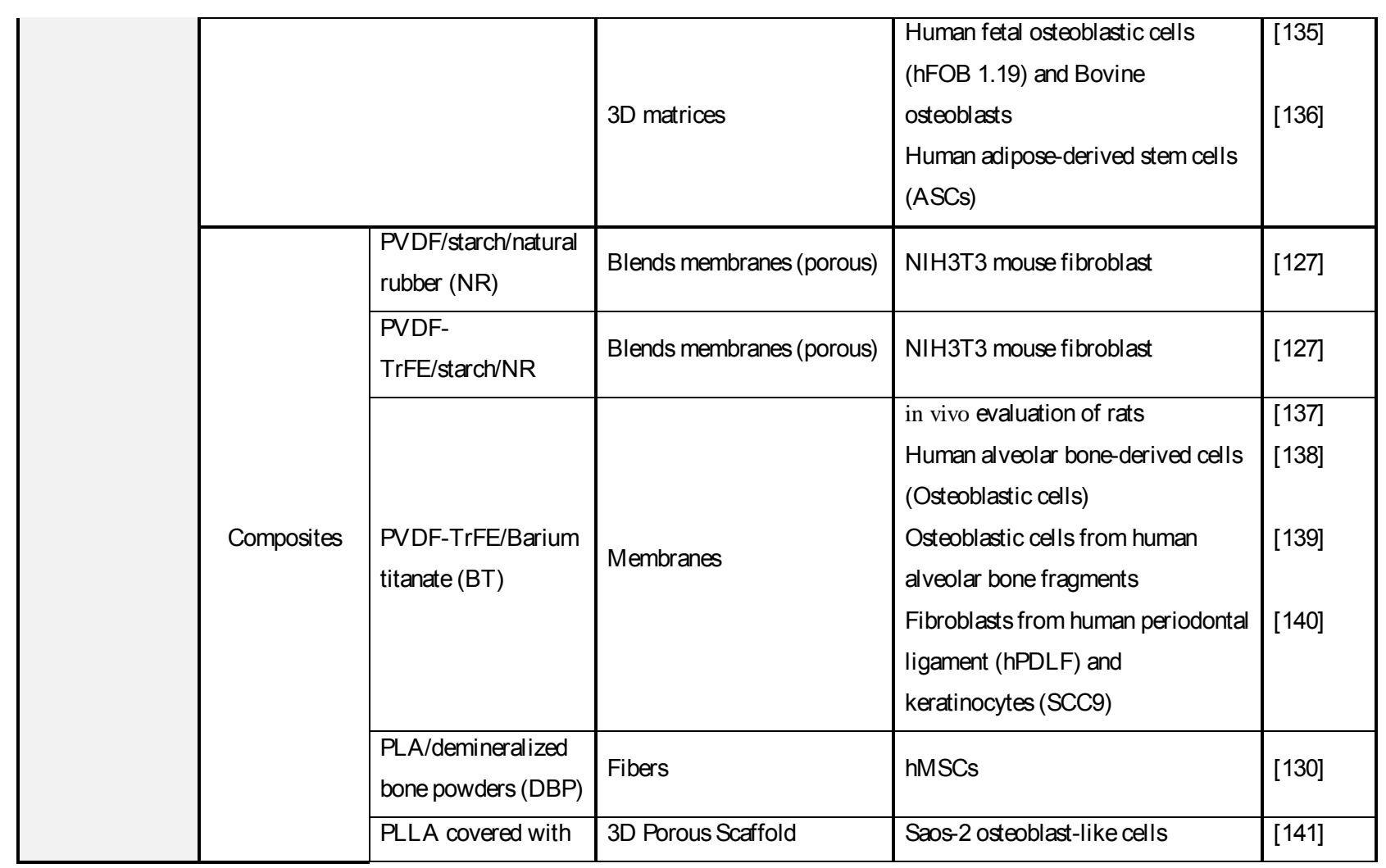




\begin{tabular}{|c|c|c|c|c|}
\hline & \multicolumn{2}{|l|}{ bonelike apatite } & \multirow[b]{2}{*}{ Saos-2 osteoblast-like cells } & \multirow[b]{2}{*}{ [141] } \\
\hline & Apatite/collagen & 3D Porous Scaffold & & \\
\hline \multirow{6}{*}{$\begin{array}{c}\text { Nerve or } \\
\text { neural } \\
\text { regeneration }\end{array}$} & \multirow{3}{*}{ PVDF } & Films & $\begin{array}{l}\text { Mouse neuroblastoma cells (Nb2a) } \\
\text { Spinal cord neurons }\end{array}$ & $\begin{array}{l}43, \\
142]^{*} \\
{[143]}\end{array}$ \\
\hline & & Blends membranes (porous) & $\begin{array}{l}\text { Dense and microporous } \\
\text { membranes: neuronal cells }\end{array}$ & [144] \\
\hline & & Channels/Tubes & $\begin{array}{l}\text { Nerve guidance channels: in vivo } \\
\text { assay: mouse sciatic nerve model. } \\
\text { Tube containing nerve growth } \\
\text { factor (NGF) and Collagen gel: in } \\
\text { vivo assay: Wistar rats. }\end{array}$ & $\begin{array}{l}{[145]} \\
{[146]}\end{array}$ \\
\hline & \multirow{3}{*}{ PVDF-TrFE } & Films & $\begin{array}{l}\text { Poietics Normal Human Neural } \\
\text { Progenitors } \\
\mathrm{Nb2a}\end{array}$ & $\begin{array}{l}{[147]} \\
{[43]}\end{array}$ \\
\hline & & Fibers & $\begin{array}{l}\text { Dorsal root ganglion } \\
\text { Poietics normal human neural } \\
\text { progenitors }\end{array}$ & $\begin{array}{l}{[148]} \\
{[147]}\end{array}$ \\
\hline & & Tubes & In vivo implementation: rat sciatic & [149] \\
\hline
\end{tabular}

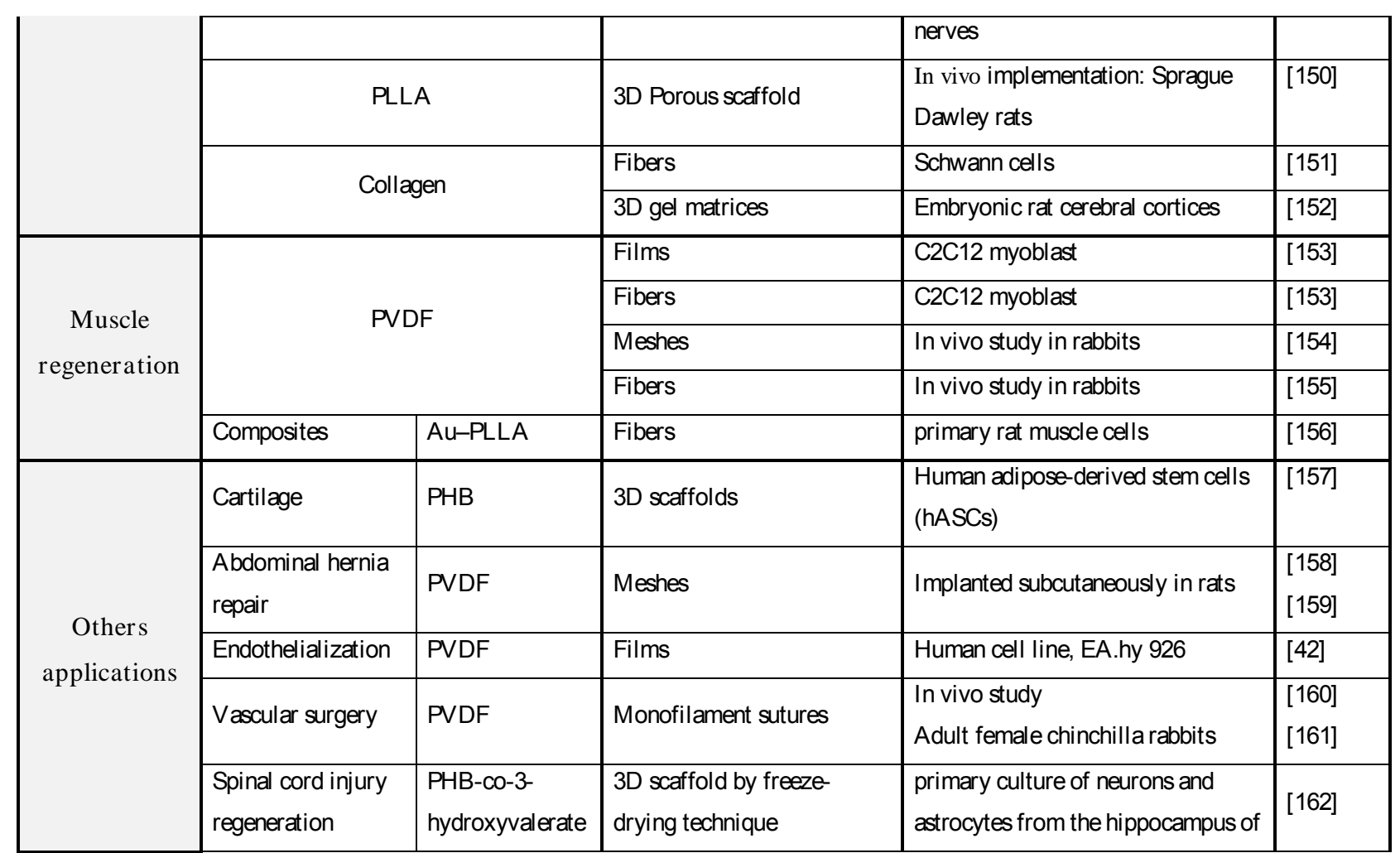




\begin{tabular}{|l|l|l|l|l|l|}
\hline & (PHB-HV) & & P4 Wistar rats & \\
\cline { 2 - 6 } & \multirow{2}{*}{ Wound healing } & PPy/PLLA & Membranes & Human Skin Fibroblast & {$[163]$} \\
\cline { 2 - 6 } & PVDF-TrFE & Electrospun fibers & Human skin fibroblasts & {$[164]$} \\
\cline { 2 - 5 } & Tissue sensors & PVDF & Microstructures & Human osteosarcoma (HOS) & {$[165]$} \\
\hline
\end{tabular}


Dynamic assays were performed in the studies marked with * contrary to the others where only static assays were carried out. It is to notice that when no dynamic conditions are used, the suitability of the piezoelectric effect is not proven, but just the suitability of the material.

It is to notice that the most used polymer is PVDF and co-polymers as, due to its larger piezoelectric response, serve as an ideal material platform for proving the concept of mechano-electrical transductions for tissue engineering. Also several sample morphologies have been used, such as films, fibers, porous membranes and 3D porous scaffolds for different applications in tissue engineering, mainly for bone, muscle and nerve regeneration. With the challenge to mimic the architecture of these tissues, the fibers have proved to be one of the favorite choices and for most of the studies mesenchymal stem cells have been chosen. For bone tissue enginering applications, PVDF fibers were produced and its effect on biological function was studied with hMSCs [126]. It was verified that the cells attach to the PVDF fibers and present a greatest alkaline phosphatase activity and early mineralization when compared with the control, showing the potential for the use of PVDF scaffolds for bone tissue enginering applications. The same cells was also used with PLLA fibers to study their biocompatibility and suitability for bone differentiation and the same results was obtained [130]. Regarding nerve regeneration, fibers was also used and it was verified that the cells attach and the neurites extend radially on the random aligned fibers, whereas the aligned fibers directed the neurite outgrowth, demonstrating their potential for neural tissue engineering [147-148].

On the other hand, despite the demonstrated potential, there is still just a few conclusive works addressing the effect of the electrical stimulus promoted by the piezoelectric response of the materials, as for these studies, specific dynamical mechanical stimulus should be applied during cell culture.

In this scope, piezoelectric materials based on PVDF films, have been used to study the effect of mechanical stimulation of bone cells, by converse piezoelectric effect. On a substrates submitted to dynamic mechanical conditions, the stimulation was achieved with an alternating sinusoidal current (AC) of $5 \mathrm{~V}$ at 1 and $3 \mathrm{~Hz}$ for $15 \mathrm{~min}$ at each frequency. It was verified that mechanical stimulation of bone induces new bone formation in vivo and increases the metabolic activity and gene expression of 
osteoblasts in culture [105-106]. The influence of the same piezoelectric substrate, PVDF film, on the bone response cultivated under static and dynamic conditions was also investigated [107]. The dynamic culture was performed on a home-made bioreactor system with mechanical stimulation by placing the culture plate on a vertical vibration module at a frequency of $1 \mathrm{~Hz}$ with amplitude of $\sim 1 \mathrm{~mm}$. The results showed that the surface charge under mechanical stimulation improves the osteoblast growth and consequently, that electroactive membranes and scaffolds can provide the necessary electrical stimuli for the growth and proliferation of electrically responsive tissue and in particular of tissues which also show piezoelectric response, such as bone. The same dynamic culture was used to enhanced osteogenic differentiation of human adipose stem cells, proving that dynamic mechanical stimulus in combination with suitable osteogenic differentiation media can offer tools to better mimick the conditions found in vivo [108].

Concerning nerve regeneration, neurons were cultured directly on electrically charged PVDF polymer growth substrates to determine if local electrical charges enhance nerve fibre outgrowth in vitro [86]. Piezoelectric PVDF substrates generated 2-3 mV at 1200 $\mathrm{Hz}$ when placed on standard incubator shelves and it was conclude that the enhanced outgrowth process was induced effectively by the piezoelectric output of the films. 
6. Final remarks, conclusions and main challenges

The tissue engineering has emerged as an alternative to conventional methods for tissue repair and regeneration, but different strategies can be chosen; as represented in Figure 3. Basically, it consists in choosing appropriate cells, materials and biochemical and physical signals to repair, maintain or regenerate the tissue function. The cells can be harvested directly from the patient or stem cells can be used to be combine with an biomaterial scaffold to grown in vitro without (route $\mathrm{B}$ of figure 3 ) or with (route $\mathrm{C}$ of figure 3) signals and then implanted. It should be also noted that the bioreactor use in tissue engineering is an attempt to simulate an in vivo physiological environment. The scaffold can also be implanted directly to facilitate the cell regeneration in vivo (route $\mathrm{A}$ of figure 3 ).

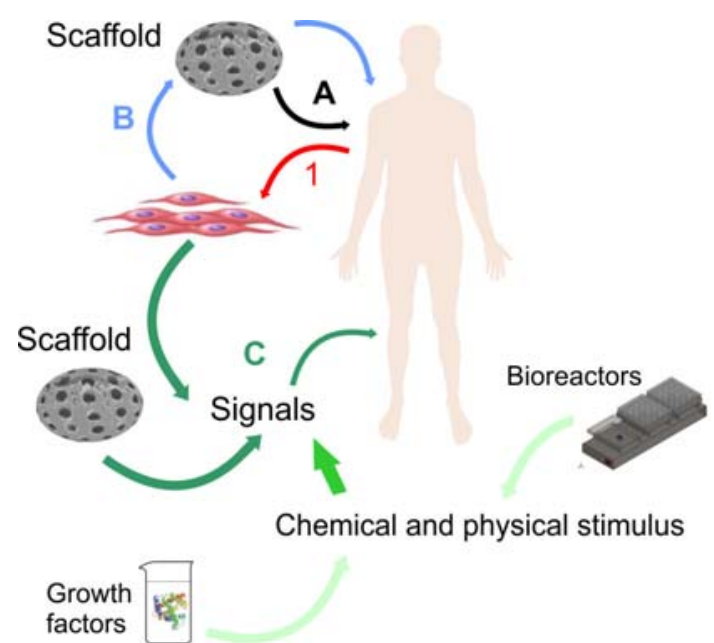

Figure 3 - Schematic representation of the different strategies of the tissue enginœring field: 1 - The cells can be harvested directly of the patient; A - Scaffold implanted directly; B - Cells cultured in scaffold and then implanted; C - Cells cultured in scaffold with appropriate signal, namely chemical (such as growth factors) and physical (such as mechanical using a bioreactor) and then implanted.

Within this general strategy, it seem evident the need of physical and biochemical stimuli giving rise to the suitable environment for tissue regeneration. In particular, it is 
proven that one of the most interesting effects to be applied in a next generation of materials is the possibility of electrical stimulation required and promote electrical stimulus to the cells, which is essential to improve functionality of the regenerated tissue.

A biomimetic approach also show the need of piezoelectric scaffolds and supports for tissue engineering applications, related to the existence of this phenomena in the living tissue.

In particular, bone, as the paradigm of piezoelectric tissue, can undergo increased regeneration success rate by applying piezoelectric related tissue engineering strategies. Thus, Figure 4 shows a promising strategy for the repair or regeneration of damaged bone. This tissue engineering therapy involves harvesting healthy cells (adult or stem cells) culturing in an appropriate scaffold for the grown in vitro in a bioreactor which will provide the proper biochemical and physical stimulus and then implanted. The main purpose of this strategy is recreating the bone tissue environment such as the biochemical and mechanical stimulus.

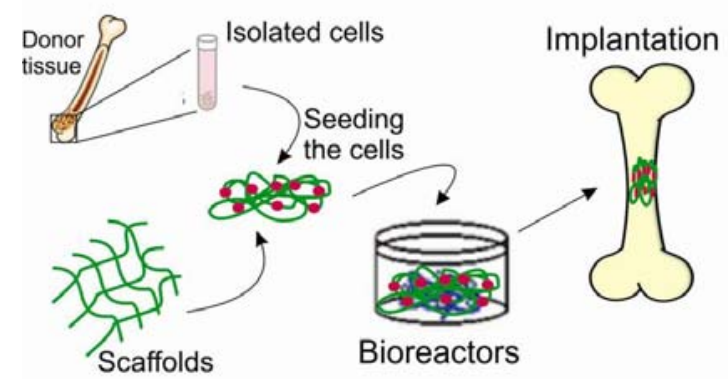

Figure 4 - Tissue engineering strategies for bone regeneration.

It can be concluded that piezoelectric materials can be used for further explore and implement tissue engineering strategies, as the materials, with suitable piezoelectric response can be tailored in terms of material properties and microstructure, as well as suitable scaffolds designs can be prepared. On the other hand, their fully potentials has not been achieved and suitable bioreactors should be developed mimicking in-vivo conditions and exploring the mechanical stimulation of the materials to get suitable electrical response. 
A new generation of studies involving bioreactors is needed before in-vivo testing in order to achieve a deep knowledge of the mechanoelectro transduction effects on the specific cells.

One this is achieved, two strategies can be followed based on piezoelectric stimulation (figure 3 and 4):

a) Bioreactor culture for pre-differentiation and cell implantation

b) Scaffold implantation

For the later a new generation of piezoelectric materials with controlled biodegradation will be needed.

\section{Acknowledgements}

This work was supported by FEDER through the COMPETE Program and by the Portuguese Foundation for Science and Technology (FCT) in the framework of the Strategic Project PEST-C/FIS/UI607/2013 and by the project Matepro - Optimizing Materials and Processes", ref. NORTE-07-0124-FEDER-000037", co-funded by the " Programa Operacional Regional do Norte" (ON.2 - O Novo Norte), under the "Quadro de Referência Estratégico Nacional" (QREN), through the "Fundo Europeu de Desenvolvimento Regional" (FEDER). CR, VS and DMC would like to acknowledge the FCT for the SFRH/BPD/90870/2012, SFRH/BD/64901/2009 and SFRH/BD/82411/2011 grants respectively. 
1. R Samatham; K J. Kim; D. Dogruer; H. R Choi; M. Konyo; J. D. Madden; Y. Nakabo; J.D. Nam; J. SH; S. Tadokoro; W. Yim; M. Yamakita, Active Polymers: An Overview. In Electroactive Polymers for Robotics Applications: Artificial Muscles and Sensors, Km, K J.; Tadokoro, S, Eds. Springer-Verlag: London, 2007.

2. J. P. Mercier; G. Zambelli; W. Kurz, Chapter 1 - Materials. In Introduction to Materials Science, Mercier, J. P.; Zambelli, G.; Kurz, W., Eds. Esevier: Oxford, 2002; pp 1-16.

3. H. Alexander; $\rfloor$ B. Brunski; S L Cooper; L L Hench; R W. Hergenrother; A. S Hoffman; J. Kohn; R Langer; N. A. Peppas; B. D. Ratner; S W. Shalaby; S. A. Visser; I. V. Yannas, CHAPTIR 2 - Gasses of Materials Used in Medicine. In Biomaterials Science, Ratner, B. D.; Lemons, A. S. H. J. S. E, Eds. Academic Press: San Diego, 1996; pp 37-130.

4. P. Fattahi; G. Yang; G. Km; M. R Abidian, Advanced Materials 2014, 26, 1846-1885. DOI 10.1002/adma.201304496.

5. J. Jordan; K I. Jacob; R Tannenbaum; M. A. Sharaf; I. Jasiuk, Materials Science and Engineering: A2005, 393, 1-11. DOI http://dx.doi.org/10.1016/j.msea.2004.09.044.

6. J. F. Mano, Macromolecular Bioscience 2009, 9, 622-622. DOI 10.1002/mabi.200900122.

7. C. A. custódio; R L Reis; J. F. Mano; A. Del Campo, Smart instructive polymer substrates for tissue engineering. In Smart Polymers and their Applications, 2014; pp 301-326.

8. P. Kumari; A. Tiwari; M. Prabaharan; S. Li, Smart polymeric materials emerging for biological applications. In Smart Polymer Materials for Biomedical Applications, 2011; pp 103118.

9. A. Kumar; A. Srivastava; I. Y. Galaev; B. Mattiasson, Progress in Polymer Science 2007, 32, 1205-1237. DOl http://dx.doi.org/10.1016/j.progpolymsci.2007.05.003.

10. M. A. C. Stuart; W. T. S Huck; J. Genzer; M. Müller; C. Ober; M. Stamm; G. B Sukhorukov; I. SJeifer; V. V. Tsukruk; M. Urban; F. Winnik; S. Zauscher; I. Lużnov; S. Minko, Nature Materials 2010, 9, 101-113. DOI 10.1038/nmat2614.

11. D. Roy; J. N. Cambre; B. S. Sumerlin, Progress in Polymer Science 2010, 35, 278-301. DOl http://dx.doi.org/10.1016/j.progpolymsci.2009.10.008.

12. C. d. I. H. Alarcon; S. Pennadam; C. Alexander, Chemical Society Reviews 2005, 34, 276285. DOl 10.1039/b406727d.

13. B. Jeong; A. Gutowska, Trends in Biotechnology 2002, 20, 305-311. DOI http://dx.doi.org/10.1016/S0167-7799(02)01962-5.

14. K J. Km; S. Tadokoro, Electroactive polymers for robotic applications: Artificial muscles and sensors. 2007; p 1-281.

15. Y. Bar-Cohen, Expert Review of Medical Devices 2005, 2, 731-740. DOI 10.1586/ 17434440.2.6.731

16. M. E Galvin, JOM 1997, 49, 52-55

17. K Gurunathan; A. V. Murugan; R Marimuthu; U. P. Mulik; D. P. Amalnerkar, Materials Chemistry and Physics 1999, 61, 173-191. DOl http://dx.doi.org/10.1016/ S02540584(99)00081-4.

18. N. K Guimard; N. Gomez; C. E Schmidt, Progress in Polymer Science 2007, 32, 876-921. DOl http://dx.doi.org/10.1016/j.progpolymsci.2007.05.012

19. B. Dhandayuthapani; Y. Yoshida; T. Maekawa; D. S. Kumar, International Journal of Polymer Science 2011, 2011. DOl 10.1155/2011/290602.

20. Q. Lu; K Ganesan; D. T. Smionescu; N. R Vyavahare, Biomaterials 2004, 25, 52275237.

21. H. S Yoo; T. G. Kim; T. G. Park, Advanced Drug Delivery Reviews 2009, 61, 1033-1042. DOl http://dx.doi.org/ 10.1016/j.addr.2009.07.007. 
22. G. Khang; J. M. Rhee; P. Shin; Y. K In; B. Lee; J. L Sang; M. L Young; B. L Hai; I. Lee, Macromolecular Research 2002, 10, 158-167.

23. J. Yuan; J. Shen; I. K Kang, Polymer International 2008, 57, 1188-1193.

24. E D. Boland; T. A. Telemeco; D. G. Smpson; G. E Wnek; G. L Bowlin, Journal of Biomedical Materials Research - Part B Applied Biomaterials 2004, 71, 144-152.

25. E D. Boland; G. E Wnek; D. G. Smpson; K J. Pawlowski; G. L Bowlin, Journal of Macromolecular Science - Pure and Applied Chemistry 2001, 38 A, 1231-1243.

26. S. W. Kang; W. G. La; B. S. Km, Journal of Biomaterials Science, Polymer Edition 2009, 20, 399-409.

27. H. J. Shao; C. S. Chen; I. C. Lee; J. H. Wang; T. H. Young, Artificial Organs 2009, 33, 309-

317.

28. J. A. Beamish; J. Zhu; K Kottke-Marchant; R E Marchant, Journal of Biomedical Materials Research - Part A2010, 92, 441-450.

29. J. Zhu, Biomaterials 2010, 31, 4639-4656.

30. M. Schappacher; M. Le Hellaye; R Bareille; M. C. Durrieu; S. M. Guillaume, Macromolecular Bioscience 2010, 10, 60-67.

31. X Liu; P. Ma, Annals of Biomedical Engineering 2004, 32, 477-486. DOI 10.1023/B:ABME0000017544.36001.8e.

32. S. Hofmann Boss; M. Garcia-Fuentes, Bioactive scaffolds for the controlled formation of complex skeletal tissues. In Regenerative medicine and tissue engineering: cells and biomaterials Eberli, D., Ed. InTech: Rjeka, 2011; pp 393 - 432.

33. R Ravichandran; S Sundarrajan; J. R Venugopal; S. Mukherjee; S Ramakrishna, Macromolecular Bioscience 2012, 12, 286-311.

34. T. Furukawa, Electrical Insulation, IEEE Transactions on 1989, 24, 375-394. DOI 10.1109/14.30878.

35. V. V. Kochervinskiĭ, Grystallography Reports 2003, 48, 649-675. DOI 10.1134/1.1595194.

36. A. D. Moore, Medical Instrumentation 1975, 9, 274-275.

37. I. S. Foulds; A. T. Barker, British Journal of Dermatology 1983, 109, 515-522. DOI 10.1111/j.1365-2133.1983.tb07673.x.

38. G. L Sulik; H. K Soong; P. C. T. Chang; W. C. Parkinson; S. G. Ener; V. M. Ener, Acta Ophthalmologica 1992, 70, 115-122.

39. M. Zhao; A. Agius-Fernandez; J V. Forrester; C. D. McCaig, Journal of Cell Science 1996, $109,1405-1414$

40. J. Pu; C. D. McCaig; L Cao; Z Zhao; J E Segall; M. Zhao, Journal of Cell Science 2007, 120, 3395-3403.

41. E Wang; M. Zhao; J. V. Forrester; C. D. McCaig, Experimental Eye Research 2003, 76, 29-37.

42. A. Bouaziz; A. Rchert; A. Caprani, Biomaterials 1997, 18, 107-112. DOI 10.1016/s01429612(96)00114-7.

43. R F. Valentini; T. G. Vargo; J. A. Gardella J; P. Aebischer, Biomaterials 1992, 13, $183-$ 190. DOI http://dx.doi.org/10.1016/0142-9612(92)90069-Z

44. P. H. G. Chao; H. H. L; C. T. Hung; S B. Nicoll; J. C. Bulinski, Connective Tissue Research 2007, 48, 188-197.

45. M. H. Shamos; L S Lavine, Nature 1967, 213, 267-\&. DOI 10.1038/213267a0.

46. J. J. Telega; R Wojnar, Piezoelectric effects in biological tissues. 2002; Vol. 40.

47. E Fukada, Biorheology 1982, 19, 15-27.

48. H. Athenstaedt, Archives of Oral Biology 1971, 16, 495-501. DOI 10.1016/00039969(71)90194-4.

49. D. De Rossi; C. Domenici; P. Pastacaldi, IEEE transactions on electrical insulation 1985 , EI-21, 511-517.

50. D. E Ingber, Scientific American 1998, 278, 48-57. 
51. N. Guzelsu; H. Demiray, International Journal of Engineering Science 1979, 17, 813-851. DOI 10.1016/0020-7225(79)90013-2.

52. I. Yasuda; K Noguchi; T. Sato, Journal of bone and joint surgery 1955, 37, 1292-1293.

53. E Fukada; I. Yasuda, Journal of the Physical Society of Japan 1957, 12, 1158-1162. DOI 10.1143/jpsj.12.1158.

54. C. A. L Bassett; R O. Becker, Science 1962, 137, 1063-\&. DOI 10.1126/science.137.3535.1063.

55. H. M. Frost, The Angle Orthodontist 1994, 64, 175-188. DOI 10.1043/00033219(1994)064<0175:wlabsa>2.0.co;2.

56. E Fukada; I. Yasuda, Journal of the Physical Society of Japan 1964, 12, 1158-1162. DOI 10.1143/JPS.12.1158

57. S Mahanian; R L Piziali, Journal of Biomechanics 1988, 21, 347-356. DOI 10.1016/0021-9290(88)90140-6.

58. A. A. Marino; R O. Becker, Nature 1970, 228, 473-\&. DOI 10.1038/228473a0.

59. S. Baiotto; M. Zdi, Biomechanics and Modeling in Mechanobiology 2004, 3, 6-16. DOI 10.1007/s10237-004-0042-y.

60. J. Ferrier; S. M. Ross; J. Kanehisa; J. E Aubin, Journal of Cellular Physiology 1986, 129, 283-288. DOI 10.1002/jcp.1041290303.

61. M. Hartig; U. Joos; H. P. Wiesmann, European Biophysics Journal 2000, 29, 499-506.

62. C. T. Brighton; E Okereke; S. R Pollack; C. C. Oark, Cinical Orthopaedics and Related Research 1992, 255-262.

63. C. T. Brighton; W. Wang; R Seldes; G. Zhang; S. R Pollack, Journal of Bone and Joint Surgery - Series A2001, 83, 1514-1523.

64. H. Zhuang; W. Wang; R M. Seldes; A. D. Tahernia; H. Fan; C. T. Brighton, Biochemical and Biophysical Research Communications 1997, 237, 225-229. DOI http://dx.doi.org/ 10.1006/ bbrc.1997.7118.

65. R Korenstein; D. Somjen; H. Fischler; I. Binderman, Biochimica et Biophysica Acta (BBA) - Molecular Cell Research 1984, 803, 302-307. DOl http://dx.doi.org/10.1016/01674889(84)90121-6.

66. S. D. Mcallen; J. P. McQuilling; R M. Grossfeld; J. L Lubischer; L I. Garke; E G. Loboa, Tissue Engineering - Part C: Methods 2010, 16, 1377-1386

67. M. Akai; Y. Shirasaki; T. Tateishi, Archives of Physical Medicine and Rehabilitation 1997 78, 405-409. DOl http://dx.doi.org/ 10.1016/ S0003-9993(97)90233-1.

68. T. Mohr; J. Pødenphant; F. Biering-Sørensen; H. Galbo; G. Thamsborg; M. Kæær, Calcified Tissue International 1997, 61, 22-25. DOI 10.1007/s002239900286.

69. C. A. L Bassett; R J. Pawluk; R O. Becker, Nature 1964, 204, 652-654.

70. C. T. Brighton; Z B. Friedenberg; L M. Zemsky; P. R Pollis, Journal of Bone and Joint Surgery - Series A 1975, 57, 368-377.

71. A. Rubinacci; J. Black; C. T. Brighton; Z B. Friedenberg, Journal of Orthopaedic Research 1988, 6, 335-345.

72. K Yonemori; S. Matsunaga; Y. Ishidou; S. Maeda; H. Yoshida, Bone 1996, 19, 173-180.

DOl http://dx.doi.org/ 10.1016/8756-3282(96)00169-X

73. K Anselme, Biomaterials 2000, 21, 667-681. DOI 10.1016/s0142-9612(99)00242-2.

74. B. Miara; E Rohan; M. Zdi; B. Labat, Journal of the Mechanics and Physics of Solids 2005, 53, 2529-2556. DOI 10.1016/j.jmps.2005.05.006.

75. E Fukada, Ieee Transactions on Ultrasonics Ferroelectrics and Frequency Control 2000, 47, 1277-1290. DOI 10.1109/58.883516.

76. C. R West; A. E Bowden, Annals of Biomedical Engineering 2012, 40, 1568-1574. DOI

10.1007/s10439-011-0504-1.

77. $\quad$ E Fukada; I. Yasuda, Japanese Journal of Applied Physics 1964, 3, 117.

78. J. C. Anderson; C. Eriksson, Nature 1970, 227, 491-492.

79. D. Gross; W. S. Williams, Journal of Biomechanics 1982, 15, 277-295. 
80. A. A. Marino; R O. Becker, Nature 1975, 253, 627-628.

81. L S. Lavine; I. Lustrin; R A. Rinaldi; M. H. Shamos; A. R Liboff, Science 1972, 175, 11181121. DOI 10.1126/science.175.4026.1118.

82. E Fukada; H. Ueda; R Rnaldi, Biophysical Journal 1976, 16, 911-918.

83. A. C. Ahn; A. J. Grodżnsky, Medical Engineering \& Physics 2009, 31, 733-741. DOI 10.1016/j.medengphy.2009.02.006.

84. S. B. Lang, Nature 1966, 212, 704-705.

85. J. C. Anderson; C. Eriksson, Nature 1968, 218, 166-168.

86. C. Halperin; S. Mutchnik; A. Agronin; M. Molotskii; P. Urenski; M. Salai; G. Rosenman, Nano Letters 2004, 4, 1253-1256. DOI 10.1021/nl049453i.

87. A. J P. Martin, Proceedings of the Physical Society 1941, 53, 186-189. DOI 10.1088/0959-5309/53/2/310.

88. S. B. Lang; A. A. Marino; G. Berkovic; M. Fowler; K D. Abreo, Bioelectrochemistry and Bioenergetics 1996, 41, 191-195. DOl http://dx.doi.org/ 10.1016/S0302-4598(96)05147-1.

89. S Ktchen, Electrotherapy: Evidence-based Practice. Ohurchill Livingstone: Edinburgh, 2002.

90. L Ghasemi-Mobarakeh; M. P. Prabhakaran; M. Morshed; M. H. Nasr-Esfahani; H. Baharvand; S. Kani; S. S. Al-Deyab; S. Ramakrishna, Journal of Tissue Engineering and Regenerative Medicine 2011, 5, e17-e35. DOI 10.1002/term.383.

91. G. G. Matthews, Cellular Physiology of Nerve and Muscle. Blackwell Publishing: Malden, USA, 2003.

92. Z Zhang; M. Rouabhia; Z Wang; C. Roberge; G. Shi; P. Roche; J. L; L H. Dao, Artificial Organs 2007, 31, 13-22. DOI 10.1111/j.1525-1594.2007.00335.x.

93. CHRSTINE E SOHMIDT; VENKATRAM R SHASTR; DSEH P. VACANT; R LANGER, Proc. Natl. Acad. Sci. 1997, 94, 8948-8953.

94. L Huang; J. Hu; L Lang; X Wang; P. Zhang; X Jing; X Wang; X Chen; P. I. Lelkes; A. G. MacDiarmid; Y. Wei, Biomaterials 2007, 28, 1741-1751. DOl 10.1016/j.biomaterials.2006.12.007.

95. H. S. Nalwa, Handbook of Organic Conductive Molecules and Polymers. Wiley: New York, 1997.

96. M. Mattioli-Belmonte; G. Giavaresi; G. Biagini; L Virgili; M. Giacomini; M.. Fini; F Giantomassi; D. Natali; P. Torricelli; R Giardino, International Journal of Artificial Organs 2003, 26, 1077-1085.

97. C. H. Wang; Y. Q. Dong; K Sengothi; K L Tan; E T. Kang, Synthetic Metals 1999, 102, 1313-1314. DOI 10.1016/s0379-6779(98)01006-6.

98. P. R Bidez; S L; A. G. MacDiarmid; E C. Venancio; Y. Wei; P. I. Lelkes, Journal of Biomaterials Science, Polymer Edition 2006, 17, 199-212. DOI 10.1163/156856206774879180.

99. R A. Green; N. H. Lovell; L A. Poole-Warren, Biomaterials 2009, 30, 3637-3644. DOI 10.1016/j.biomaterials.2009.03.043

100. B. S. Harrison; A. Atala, Biomaterials 2007, 28, 344-353. DOI 10.1016/j.biomaterials.2006.07.044.

101. Y. Zhu; W. Li, Science in China Series B: Chemistry 2008, 51, 1021-1029. DOI 10.1007/s11426-008-0120-6.

102. X Wang; X Gu; C. Yuan; S. Chen; P. Zhang; T. Zhang; J. Yao; F. Chen; G. Chen, Journal of Biomedical Materials Research - Part A2004, 68, 411-422.

103. A. J. Lovinger, Developments in semicrystalline polymers. Esevier Applied Sciences: London, 1982.

104. C. Liu; Z Xa; J. T. Czernuszka, Chemical Engineering Research and Design 2007, 85, 1051-1064. DOl http://dx.doi.org/10.1205/cherd06196.

105. E Fallahiarezoudar; M. Ahmadipourroudposht; A. Idris; N. Mohd Yusof, Materials Science and Engineering: C 2015, 48, 556-565. DOI http://dx.doi.org/10.1016/j.msec.2014.12.016. 
106. L Zhang; Y. Morsi; Y. Wang; Y. Li S. Ramakrishna, Japanese Dental Science Review 2013, 49, 14-26. DOI http://dx.doi.org/10.1016/j.jdsr.2012.09.001.

107. F. J. O'Brien, Materials Today 2011, 14, 88-95. DOl http://dx.doi.org/10.1016/S13697021(11)70058-X

108. D. M. Correia; R Goncalves; C. Rbeiro; V. Sencadas; G. Botelho; J. L G. Rbelles; S. Lanceros-Mendez, RSC Advances 2014, 4, 33013-33021. DOI 10.1039/ C4RA04581E

109. C. Rbeiro; D. M. Correia; S. Ribeiro; V. Sencadas; G. Botelho; S. Lanceros-Méndez, Engineering in Life Sciences 2015, n/a-n/a. DOI 10.1002/elsc.201400144.

110. G. Wei; P. X Ma, 2 - Polymeric biomaterials for tissue engineering. In Tissue Engineering Using Ceramics and Polymers (Second Edition), Boccaccini, A. R; Ma, P. X, Eds. Woodhead Publishing: 2014; pp 35-66.

111. E Fallahiarezoudar; M. Ahmadipourroudposht; A. Idris; N. Mohd Yusof, Materials Science and Engineering C2015, 48, 556-565. DOI 10.1016/j.msec.2014.12.016.

112. D. Rana; S. Arulkumar; A. Vishwakarma; M. Ramalingam, Chapter 10 - Considerations on Designing Scaffold for Tissue Engineering. In Stem Cell Biology and Tissue Engineering in Dental Sciences, Ramalingam, A. V. S S. Ed. Academic Press: Boston, 2015; pp 133-148.

113. J. Serrado Nunes; A. Wu; J. Gomes; V. Sencadas; P. Vilarinho; S Lanceros-Méndez, Applied Physics A: Materials Science \& Processing 2009, 95, 875-880. DOI 10.1007/ s00339-0095089-2.

114. H. S Nalwa, Ferroelectric Polymers: Chemistry, Physics, and Applications. Marcel Dekker, Inc: New York, 1995.

115. S. Hikosaka; H. Ishikawa; Y. Ohki, Electronics and Communications in Japan 2011, 94, 18. DOI 10.1002/ ecj.10348.

116. T. Ochiai; E Fukada, Journal of Japanese Applied Physics 1998, 37, 3374-3376. DOI 10.1143/JAP.37.3374.

117. J. A. Malmonge; L F. Malmonge; G. C. Fuzari; S. M. Malmonge; W. K Sakamoto, Polymer Composites 2009, 30, 1333-1337. DOI 10.1002/pc.20719.

118. E Fukada; Y. Ando, International Journal of Biological Macromolecules 1986, 8, 361366. DOl http://dx.doi.org/ 10.1016/0141-8130(86)90056-5.

119. J. Gomes; J. S. Nunes; V. Sencadas; S. Lanceros-Mendez, Smart Materials and Structures 2010, 19.

120. P. Martins; A. C. Lopes; S. Lanceros-Mendez, Progress in Polymer Science 2014, 39, 683-706. DOI http://dx.doi.org/10.1016/j.progpolymsci.2013.07.006.

121. P. Frubing; A. Kremmer; R Gerhard-Multhaupt; A. Spanoudaki; P. Pissis, The Journal of Chemical Physics 2006, 125, 214701-8.

122. C. Frias; J. Reis; F. Capela e Slva; J Potes; J. Smões; A. T. Marques, Journal of Biomechanics 2010, 43, 1061-1066. DOI http://dx.doi.org/10.1016/j.jbiomech.2009.12.010.

123. J. Reis; C. Frias; C. Canto e Castro; M. L Botelho; A. T. Marques; J. A. O. Simoes; F. Capela e Slva; J. Potes, Journal of biomedicine \& biotechnology 2012, 2012, 613403-613403. DOl 10.1155/2012/613403.

124. C. Rbeiro; S Moreira; V. Correia; V. Sencadas; J. G. Rocha; F. M. Gama; J L Gomez Rbelles; S. Lanceros-Mendez, Rsc Advances 2012, 2, 11504-11509. DOI 10.1039/c2ra21841k.

125. M. T. Rodrigues; M. E Gomes; J. F. Mano; R L Reis, beta-PVDF Membranes Induce Cellular Proliferation and Differentiation in Static and Dynamic Conditions. In Advanced Materials Forum Iv, Marques, A. T.; Slva, A. F.; Baptista, A. P. M.; Sa, C.; Alves, F.; Malheiros, L F.; Vieira, M., Eds. 2008; Vol. 587-588, pp 72-76.

126. S. M. Damaraju; S Wu; M. Jaffe; T. L Arinzeh, Biomedical Materials 2013, 8. DOI 045007

10.1088/1748-6041/8/4/045007.

127. L Marques; L A. Holgado; R D. Smoes; J. Pereira; J. F. Horiano; L Mota; C. F. O. Graeff; C. J. L Constantino; M. A. Rodriguez-Perez; M. Matsumoto; A. Knoshita, Journal of 
Biomedical Materials Research Part B-Applied Biomaterials 2013, 101, 1284-1293. DOI 10.1002/jbm.b.32941.

128. Y. Ikada; Y. Shikinami; Y. Hara; M. Tagawa; E Fukada, Journal of Biomedical Materials Research 1996, 30, 553-558.

129. M. P. Prabhakaran; J. Venugopal; S. Ramakrishna, Acta Biomaterialia 2009, 5, 28842893. DOI 10.1016/j.actbio.2009.05.007.

130. E K Ko; S. I. Jeong; N. G. Rm; Y. M. Lee; H. Shin; B.-K Lee, Tissue Engineering Part A 2008, 14, 2105-2119. DOI 10.1089/ten.tea.2008.0057.

131. Y.-W. Wang; Q. Wu; J. Chen; G.-Q. Chen, Biomaterials 2005, 26, 899-904. DOI http://dx.doi.org/10.1016/j.biomaterials.2004.03.035.

132. E I. Paşcu; J. Stokes; G. B. McGuinness, Materials Science and Engineering: C 2013, 33, 4905-4916. DOl http://dx.doi.org/10.1016/j.msec.2013.08.012.

133. C. Mota; S-Y. Wang; D. Puppi; M. Gazzarri; C. Migone; F. Chiellini; G.Q. Chen; E Chiellini, Journal of Tissue Engineering and Regenerative Medicine 2014, n/a-n/a. DOI 10.1002/term.1897.

134. D. Denning; M. T. Abu-Rub; D. I. Zeugolis; S. Habelitz; A. Pandit; A. Fertala; B. J. Rodriguez, Acta Biomaterialia 2012, 8, 3073-3079.

135. P. L Moreira; Y. H. An; A. Rodrigues Santos J; S. Candelária Genari, Journal of Biomedical Materials Research - Part B Applied Biomaterials 2004, 71, 229-237.

136. N. Kakudo; A. Shimotsuma; S. Miyake; S. Kushida; K Kusumoto, Journal of Biomedical Materials Research Part A2008, 84A, 191-197. DOI 10.1002/jbm.a.31311.

137. R Gimenes; M. A. Zaghete; M. Bertolini; J A Varela; L O. Coelho; N. F. Slva, Composites PVDF-TrFE/BT used as bioactive membranes for enhancing bone regeneration. In Smart Structures and Materials 2004: Electroactive Polymer Actuators and Devices, BarCohen, Y., Ed. 2004; Vol. 5385, pp 539-547.

138. L N. Teixeira; G. E Orippa; R Gimenes; M. A. Zaghete; P. T. de Oliveira; A. L Rosa; M. M. Beloti, Journal of Materials Science-Materials in Medicine 2011, 22, 151-158. DOl 10.1007/s10856-010-4189-z

139. M. M. Beloti; P. T. de Oliveira; R Gimenes; M. A. Zaghete; M. J. Bertolini; A. L Rosa Journal of Biomedical Materials Research Part A 2006, 79A, 282-288. DOI 10.1002/jbm.a.30801.

140. L N. Teixeira; G. E Orippa; A. C. Trabuco; R Gimenes; M. A. Zaghete; D. B. Palioto; P. T. de Oliveira; A. L Rosa; M. M. Beloti, Acta Biomaterialia 2010, 6, 979-989. DOI 10.1016/j.actbio.2009.08.024

141. Y. Chen; A. F. T. Mak; M. Wang; J. ن i M. S. Wong, Surface \& Coatings Technology 2006, 201, 575-580. DOI 10.1016/j.surfcoat.2005.12.005

142. R F. Valentini; T. G. Vargo; J. A. Gardella; P. Aebischer, Journal of Biomaterials Science, Polymer Edition 1994, 5, 13-36. DOI 10.1163/156856294x00626.

143. N. Royo-Gascon; M. Wininger; J. I. Scheinbeim; B. L Frestein; W. Oraelius, Annals of Biomedical Engineering 2013, 41, 112-122.

144. T.-H. Young; H.-H. Chang; D.-J Lin; L-P. Cheng, Journal of Membrane Science 2010,

350, 32-41. DOI 10.1016/j.memsci.2009.12.009.

145. P. Aebischer; R F. Valentini; P. Dario; C. Domenici; P. M. Galletti, Brain Research 1987, 436, 165-168.

146. H. Delaviz; A. Faghihi; A. A. Delshad; M. H. Bahadori; J. Mohamadi; A. Roozbehi, Cell Journal 2011, 13, 137-142.

147. Y. S. Lee; T. L Arinzeh, Tissue Engineering - Part A 2012, 18, 2063-2072.

148. Y. S Lee; G. Collins; T. Livingston Arinzeh, Acta Biomaterialia 2011, 7, 3877-3886.

149. E G. Fine; R F. Valentini; R Bellamkonda; P. Aebischer, Biomaterials 1991, 12, 775-

780. 
150. G. R D. Evans; K Brandt; A. D. Niederbichler; P. Chauvin; S. Hermann; M. Bogle; L Otta; B. Wang; C. W. Patrick, Journal of Biomaterials Science, Polymer Edition 2000, 11, 869878. DOl 10.1163/156856200744066.

151. R C. de Guzman; J. A. Loeb; P. J VandeVord, Journal of Biomaterials Science -- Polymer Edition 2010, 21, 1081-1101. DOI 10.1163/092050609x12457428936116.

152. T. J. O'Shaughnessy; H. J. Lin; W. Ma, Neuroscience Letters 2003, 340, 169-172. DOI http://dx.doi.org/10.1016/SO304-3940(03)00083-1.

153. P. M. Martins; S Rbeiro; C. Rbeiro; V. Sencadas; A. C. Gomes; F. M. Gama; S Lanceros-Mendez, Rsc Advances 2013, 3, 17938-17944. DOI 10.1039/c3ra43499k.

154. P. L Jansen; U. Kinge; M. Anurov; S. Titkova; P. R Mertens; M. Jansen, European Surgical Research 2004, 36, 104-111. DOI 10.1159/000076650.

155. A. Inui; T. Kokubu; T. Makino; I. Nagura; N. Toyokawa; R Sakata; M. Kotera; T. Nishino; H. Fujioka; M. Kurosaka, International Orthopaedics 2010, 34, 1327-1332. DOI 10.1007/s00264-009-0917-8.

156. K D. McKeon-Fischer; J. W. Freeman, Journal of Tissue Engineering and Regenerative Medicine 2011, 5, 560-568. DOl 10.1002/term.348.

157. C. Ye; P. Hu; M.-X Ma; Y. Xang; R-G. Liu; X-W. Shang, Biomaterials 2009, 30, 44014406. DOl http://dx.doi.org/10.1016/j.biomaterials.2009.05.001.

158. C. D. Kink; K Junge; M. Binnebeosel; H. P. Alizai; J. Otto; U. P. Neumann; U. Kinge, Journal of Investigative Surgery 2011, 24, 292-299. DOI 10.3109/08941939.2011.589883.

159. U. Winge; B. Kosterhalfen; A. P. Ottinger; K Junge; V. Schumpelick, Biomaterials 2002, 23, 3487-3493. DOI Pi s0142-9612(02)00070-4

10.1016/s0142-9612(02)00070-4.

160. G. Laroche; Y. Marois; E Schwarz; R Guidoin; M. W. Kng; E Paris; Y. Douville, Artificial Organs 1995, 19, 1190-1199. DOl 10.1111/j.1525-1594.1995.tb02282.x.

161. J. Conze; K Junge; C. Weiss; M. Anurov; A. Oettinger; U. Kinge; V. Schumpelick, Journal of Biomedical Materials Research Part B-Applied Biomaterials 2008, 87B, 321-328. DOI 10.1002/jbm.b.31106.

162. S. Rbeiro-Samy; N. A. Slva; V. M. Correlo; J. S. Fraga; L Pinto; A. Teixeira-Castro; H. Leite-Almeida; A. Almeida; J. M. Gimble; N. Sousa; A. J. Salgado; R L Reis, Macromolecular Bioscience 2013, 13, 1576-1592.

163. M. Rouabhia; H. Park; S. Y. Meng; H. Derbali; Z Zhang, Plos One 2013, 8. DOI 10.1371/journal.pone.0071660.

164. N. Weber; Y. S. Lee; S. Shanmugasundaram; M. Jaffe; T. L Arinzeh, Acta Biomaterialia 2010, 6, 3550-3556. DOI http://dx.doi.org/ 10.1016/j.actbio.2010.03.035.

165. D. Gallego; N. J. Ferrell; D. J. Hansford, MRS Online Proceedings Library 2007, 1002, null-null. DOI doi:10.1557/PROC-1002-N04-05. 